\title{
ABOUT A NECESSITY OF A COMPLEX APPROACH TO FORENISC-MEDICAL DIAGNOSING OF "BUMPER-FRACTURES"
}

\section{P.V. Plevinskis}

Abstract. Complex questions of forensic-medical diagnosing of a road accident injury are dealt with in this paper: namely, the mechanism of "bumper-fractures" forming. It is corroborated, that only while studying the morphology of a fracture, it is difficult to determine its origin, and an "integrated approach" for forensic medical diagnostics of a "bumperfracture" is suggested.

Key words: motor-vehicle injury, bumper-fracture, morphology

Regional Bureau of Forensic-Medical Examination (Odessa)

Рецензент - проф. В.Т. Бачинський
Buk. Med. Herald. - 2013. - Vol. 17, № 3 (67), part 1. - P. 125-127

Надійшла до редакції 07.06.2013 року

(C) П.В. Плевинскис, 2013

УДК 340.66:616-001.4-091.8:623.446.3

\section{А.О. Плетенецька}

\section{СУДОВО-ЦИТОЛОГІЧНІ ОЗНАКИ УШКОДЖЕНЬ ТІЛА ЛЮДИНИ ПРИ ПОСТРІЛАХ ІЗ ПНЕВМАТИЧНОЇ ГВИНТІВКИ СRОSМАN 2100 CLASSIC}

Національна медична академія післядипломної освіти ім. П.Л. Шупика, м. Київ

Резюме. Проведені цитологічні дослідження мікронакладень на кулях BBs та Skarabey DS, що були вилучені з ранових каналів при пострілах у стегна трупів із потужної пневматичної гвинтівки Crosman 2100 CLASSIC. Вивчення змивів із куль, незалежно від відстані пострілу, дозволило встановити мікроскопічну картину. Це може бути використано в судово-медичній практиці при проведенні експертиз із приводу ушкоджень із цього виду зброї.

Ключові слова: пневматична гвинтівка, куля, клітина, препарат.

Постріли проводили 3 мисливської американської ПГ Crosman 2100 Classic сталевими обмідненими кульками $\mathrm{BBs}$, свинцевими кулями Skarabey DS з відстаней - 0, 1, 3, 5, 10, 15, 25 і 50 см; 1, 2, 4, 6, 8 і 10 м (по шість пострілів у кожний об'єкт). Накопичення енергії для кожного пострілу здійснювалося десятьма качками цівки гвинтівки. Середня швидкість куль склала 236,4 м/с. Постріли в біоманекени робили в передню й бічні поверхні стегна, після чого вилучали кулю за допомогою пінцета. Цитологічний метод дослідження використовували за допомогою горизонтальної хроматографії, з опадів приготували 168 препаратів. Далі дослідження проводили методом імерсійної мікроскопії за допомогою мікроскопа «Біолам», окуляри - х7, об'єктиви - х10 й x90.

Результати дослідження та їх обговорення. Цитологічне дослідження мікронакладень на кулях дозволило встановити наступні факти: при пострілах обмідненою кулькою BBs 3 потужної ПГ CROSMAN 2100 Classic із різних відстаней мікроскопічна картина украй мізерна: по всьому полю зору трапляються поодинокі без'ядерні клітини, дрібна кокова мікрофлора, фон препаратів ніжно-рожевого кольору (рис. 1).

Цитологічне дослідження мікронакладень на кулях типу Skarabey DS показало, що препарати 


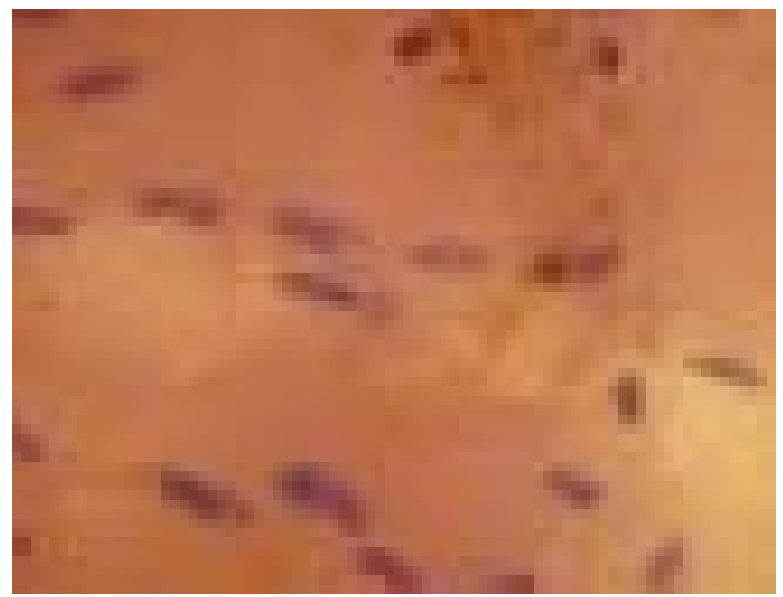

Рис. 1. Мікропрепарат гладенької м'язової тканини. Поодинокі без'ядерні клітини, дрібна кокова мікрофлора; забарвлення азур - еозином; х90
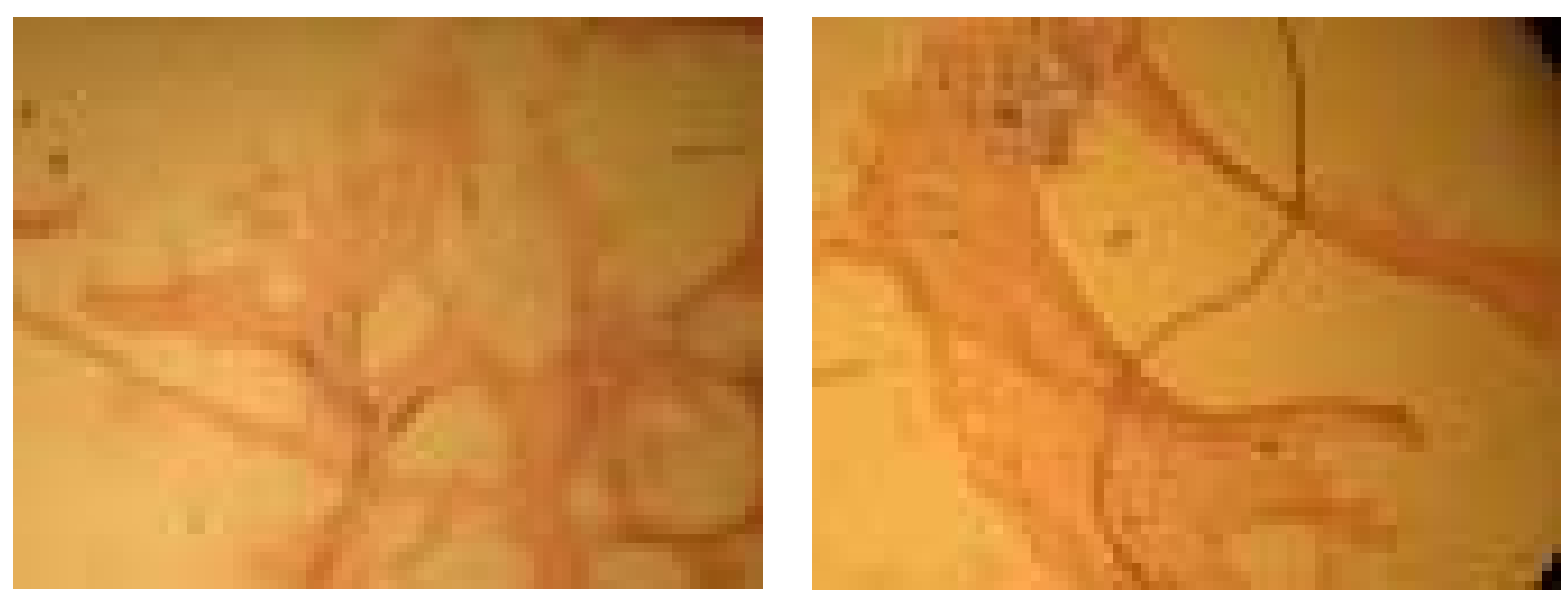

Рис. 2, 3. Мікропрепарати зразків змиву з куль типу Skarabey DS: пласти гладенької м'язової тканини з включеннями кровоносних судин; забарвлення азур - еозином; х90.

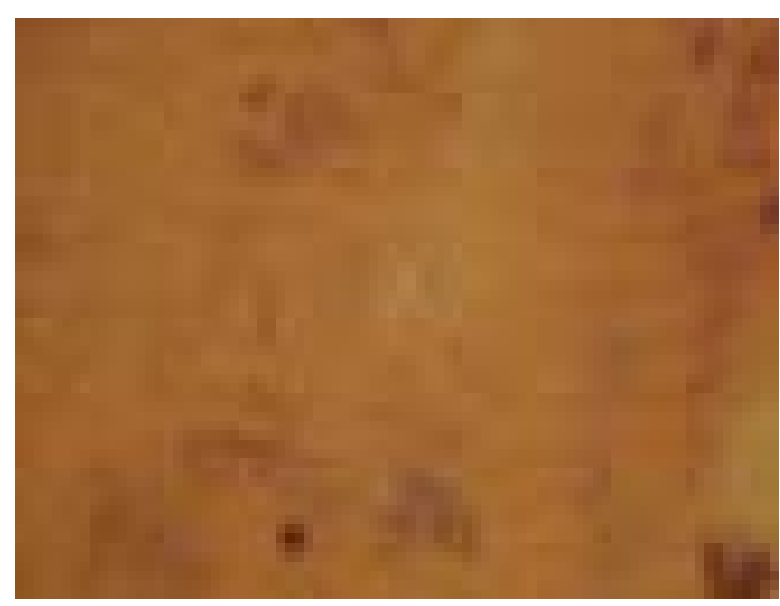

Рис. 4. Мікропрепарат зразка змива з куль типу Skarabey DS: пласти гладенької м'язової тканини з включеннями кровоносних судин; забарвлення азур - еозином; х90

значно густіші: пласти жирової тканини, що оточені чисельними волокнами сполучної тканини з включеннями фібрину; пласти гладенької м'язової тканини з включеннями кровоносних судин; пухка сполучна тканина, причому виявлено ділянки тканин поперечносмугастої мускулатури. Слід відмітити значну варіабельність м'язових волокон за довжиною. Спостерігаються м'язові волокна, ядра яких тісно прилягають й розташовуються у вигляді ланцюга (рис. 2, 3).
Однак таке розташування ядер спостерігається не на всьому протязі м'язового волокна, а лише в кінцевих відділах представлених фрагментів (рис. 4).

\section{Висновки}

1. Цитологічне дослідження мікронакладень на кулях дозволило встановити, що при пострілах обмідненою кулькою $\mathrm{BBs}$ iз різних відстаней мікроскопічна картина украй мізерна.

2. Цитологічне дослідження мікронакладень на кулях Skarabey DS показало, що препарати значно густіші, зі значною варіабельністю м'язових волокон за довжиною.

3. Все викладене дозволяє науково аргументовано включити цитологічні дослідження на об’єктах судово-медичної експертизи при ушкодженнях при пострілах із ПГ CROSMAN 2100 CLASSIC $з$ різних дистанцій у комплекс лабораторних методів для діагностики виду, типу зброї та механізму травматизації.

Перспективи подальших досліджень. На підставі результатів дослідження буде розроблено й опрацьовано методику цитологічних досліджень на об'єктах судово-медичної експертизи при ушкодженнях при пострілах із ПГ CROSMAN 2100 CLASSIC із різних дистанцій у комплекс лабораторних методів для діагностики 
виду, типу зброї та механізму травматизації. Це дозволить робити більш обгрунтовані висновки про їх наявність або відсутність на досліджуваному об'єкті клітин м'яких тканин людини для вирішення питань щодо характеру ушкоджень, виду застосованих куль та відстані пострілу.

\section{Література}

1. Автандилов Г.Г. Медицинская морфометрия / Г.Г. Автандилов. - М.: Медицина, 1990. - 384 с.

2. Бабій Л.М. Проблема вивчення пошкоджень, що заподіяні пострілами 3 пневматичної газобалонної зброї в судово-медичній практиці України та Росії / Л.М. Бабій: матеріали наук.-практ. конф. молодих вчених [«Досягнення молодих вчених - майбутнє медицини»] (22.11.2005). - Харків, 2005. - С. 7-8.

3. Зеленский С.А. Судебно-медицинская оценка повреждений, причиненных из пневматического оружия различными видами пуль: автореф. дисс. на соиск. уч. степени канд. мед. наук: спец. 14.00.24 «Судебная медицина» / С.А. Зеленский. - М., 2001. - 20 с.

4. Информативность лабораторных технологий с позиций доказательной медицины / В.Л. Эммануэль, Ю.В. Эммануэль, А.А. Генкин [и др.] // Клин. лаб. диагност. - 2002. - № 9. - С. 8.

5. Козаченко I.М. Судово-медична діагностика ушкоджень із пневматичної зброї на сучасному етапі /
I.M. Козаченко // Укр. суд.-мед. вісник. - 2008. № 1. - С. 23-27.

6. Недоліки і проблеми організації судово-медичних заходів в умовах надзвичайних ситуацій з масовими жертвами людей в Україні / В.В. Войченко, В.Д. Мішалов, О.І. Герасименко [та ін.]: зб. наук. праць НМАПО ім. П.Л. Шупика. - К., 2008. - С. 209.

7. Тагаев Н.Н. Направления исследования повреждений пневматическим оружием / Н.Н. Тагаев, В.В. Хижняк // Бокаріусовські читання: матеріали II наук.практ. конф. судов. медиків і криміналістів, присвяч. 60-річчю Харківськ. товариства судових медиків і криміналістів ім. проф. М.М. Бокаріуса (Харків, 28-29 лист. 2008 р.). - Х., 2008. - С. 104.

8. Трофимов В.Н. Пули для пневматического оружия. Справочник / В.Н. Трофимов. - М.: Издательский Дом Рученькиных, 2005. - 160с.

9. Monticelli F. Air rifle injury with an entrance through the nose: a case report and review of the literature / F. Monticelli, S. Seidl, P. Betz // Int. J. Legal. Med. - 2002. Vol. 116, № 5. - P. 292-294.

10. Robertson B.C. High-energy ballistic and avulsive injuries. A management protocol for the next millenium / B.C. Robertson, P.N. Manson // Surg. Clin. North. Am. 2010. - № 11. - P. 1589-1502.

\section{СУДЕБНО- ЦИТОЛОГИЧЕСКИЕ ПРИЗНАКИ ПОВРЕЖДЕНИЙ ТЕЛА ЧЕЛОВЕКА ПРИ ВЫСТРЕЛАХ ИЗ ПНЕВМАТИЧЕСКОЙ ВИНТОВКИ СRОSМАN 2100 CLASSIC}

\section{А.А. Плетенецкая}

Резюме. Проведенные цитологические исследования микроналожений на пулях Bbs и Skarabey DS, которые были изъяты из раневых каналов при выстрелах в бедра трупов из мощной пневматической винтовки Crosman 2100 CLASSIC. Изучение смывов с пуль, независимо от расстояния выстрела, позволило установить микроскопическую картину. Вышеприведенное может быть использовано в судебно-медицинской практике при проведении экспертиз по поводу повреждений из этого вида оружия.

Ключевые слова: пневматическая винтовка, пуля, клетка, препарат.

\section{FORINSIC - CYTOLOGIC SIGNS OF INJURIES OF THE HUMAN BODY CAUSED BY SHOTS FROM THE AIR RIFLE CROSMAN 2100 CLASSIC}

\section{A.O. Pletenets'ka}

Abstract. The author has carried out cytologic studies of microimposings on the Bbs and Skarabey DS bullets which have been withdrawn from wound channels caused by shots in the hips of corpses from the powerful pneumatic rifleCrosman 2100 CLASSIC. Studying washouts from bullets, irrespective of the shot distance, has enabled to establish a microscopic picture. The aforesaid can be used in the medicolegal practice, while carrying out examinations, concerning injuries from this type of weapon.

Key words: pneumatic rifle, bullet, cell, specimen.

National Medical Academy named after P.L. Shupyk (Kyiv)

Рецензент - проф. В.Т. Бачинський

Buk. Med. Herald. - 2013. - Vol. 17, № 3 (67), part 1. - P. 127-129

Надійшла до редакції 08.05.2013 року

(C) А.О. Плетенецька, 2013 